\title{
Comparative analysis of a cooling systems working on an environmentally friendly refrigerants
}

\author{
Adam RUCIŃSKI*1, Mateusz DALBA ${ }^{2}$, and Rafał LASKOWSKI ${ }^{1}$ \\ ${ }^{1}$ Faculty of Power and Aeronautical Engineering, Warsaw University of Technology, Warsaw, Poland \\ ${ }^{2}$ Montostal Sp. z o. o., Warsaw, Poland
}

\begin{abstract}
The paper treats with refrigerants which affect on excessive heating of atmosphere. They are in group offluorinated greenhouse gases which are regulated by European and polish law. The main aim is to lower their amount in industry leading to overall removal from use. We present possible way to design refrigeration system lowering their adverse effect on natural environment. So three options of cooling systems are analyzed: one-stage refrigeration system working with R449A, cascade refrigeration system with R744 (carbon dioxide)/ R134a and R717 (ammonia) refrigeration plant. Due to the nowadays raising use of the cascade systems, an analysis of the operating parameters of such installation was carried out with considering the cascade heat exchanger as a condenser/evaporator. The installations concerned are three alternative offers for meat processing manufactory. A thermal balance was prepared for chambers located in building and the operating parameters of the installation were assumed. The equipment corresponding to the required cooling capacities were selected.
\end{abstract}

Keywords: refrigeration systems, refrigerants, cascade cooling equipment, economic analysis

\section{Introduction}

Scientists agree that anthropogenic activity is a huge source of carbon dioxide emission into the atmosphere. $\mathrm{CO}_{2}$ is one of gases responsible for global warming of Earth's atmosphere [6]. In HVACR industry ere are used refrigerants (fluorinated gases, greenhouse gases) with high value of GWP (Global Warming Potential) and technology with increasing carbon footprint (Fig. 1). That is why strong need in European Union to limit $\mathrm{CO} 2$ emission to atmosphere is observed.

\section{Global Atmosphere Warming}
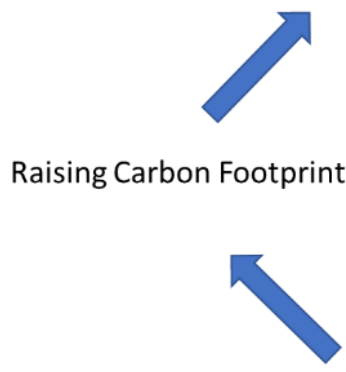

Raising Carbon Footprint

Figure 1. Vicious cycle' to break by all of us

$\mathrm{CO}_{2}$ emmision
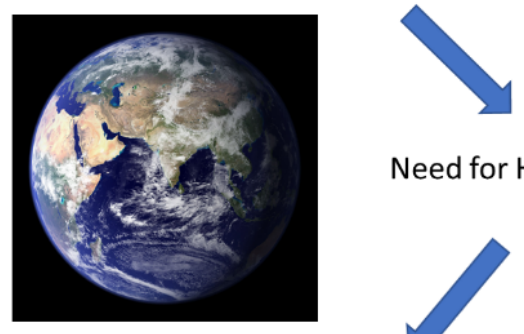

Need for HVAC\&R Technology

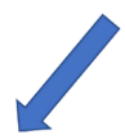

There are some tips on how to implement good practices in technology and everyday life: producing electricity from renewable energy sources, increasing energy efficiency, using biofuels in transportation and reducing vehicles carbon

\footnotetext{
${ }^{*}$ Corresponding author: E-mail address: adam.rucinski@pw.edu.pl (Adam RUCIŃSKI)
} 
footprint. Moreover, there are reduction of fluorinated refrigerants in HVACR industry and public transport instead of driving by car. In large cities people are encouraged to choose walking, bike or carpool to get their destinations. Other ones are using reusable containers or bottles instead of individual plastic ones and to eat less red meat.

Moreover, there are some law to be followed. First, the Regulation (EU) No 517/2014 of the European Parliament and of the Council of 16 April 2014 on fluorinated greenhouse gases and repealing Regulation (EC) No. 842/2006 and Regulation of the European Parliament and of the Council (EC) No 1005 / 2009 of 16 September 2009 on substances that deplete the ozone layer [15].

There are also regulations that creates certification of a personnel, manufacturers and companies:

- Commission Implementing Regulation (EU) 2015/2067 of November 17, 2015 (stationary refrigeration, airconditioning and heat pump equipment as well as refrigeration units for trucks and refrigerated trailers)

- Commission Regulation (EC) No 304/2008 of April 2, 2008 (stationary fire protection systems and fire extinguishers)

- Commission Implementing Regulation (EU) 2015/2066 of 17 November 2015 (electric switchgears)

- Commission Regulation (EC) No 306/2008 of 2 April 2008 (solvents based on fluorinated greenhouse gases)

The implementation of European regulations into Polish law resulted from the adoption of the Act of 15 May 2015 on substances that deplete the ozone layer and on some fluorinated greenhouse gases. The Act was amended by the Act of 12 July 2017 amending the act on substances that deplete the ozone layer and on some fluorinated greenhouse gases and some other acts, hereinafter referred to as the "amending act". The Amending Act came into force on 23 September 2017 and implements the provisions of Regulation (EC) No. 517/2014 of the European Parliament and of the Council of April 16, 2014 on fluorinated greenhouse gases, repealing the Regulation (EC) No. 842/2006 into national law.

In Europe, after the phase-out of CFCs, the use of HFC refrigerants is now being intensively reduced. From the 1st of January 2020 there is the ban on stationary refrigeration equipment that contains HFCs with a GWP of 2,500 or greater, except for equipment designed to cool below $-50^{\circ} \mathrm{C}$. Then, from the 1st of January 2022 it will be the ban of multi-aggregate centralised refrigeration systems for commercial use with a capacity of 40kW or more that contain fluorinated greenhouse gases with a GWP of 150 or more, apart from first-stage cascade systems which may use greenhouse gases with a GWP of 1500 or more $[3,5,7,14]$.

\section{Method}

Industry branches have to adapt mentioned regulations, technologies have to be be rebuilt. It is the reason for analysis of one-stage refrigeration system working with R449A refrigerant, cascade refrigeration system with R744 (carbon dioxide)/ R134a and R717 (ammonia) refrigeration plant. These systems could be applied in different branches of industry.

\section{$2.1 \quad$ Refrigerants}

$\mathrm{R} 449 \mathrm{~A}$ refrigerant $(\mathrm{GWP}=1397,64 \%$ lower than $\mathrm{R} 404 \mathrm{~A})$ is a mixture of R32, R125, R134a and R1234yf. It is nonflammable, due to the presence of the extinguishing compound R125. Therefore, it has been awarded Safety Class A1 according to ASHRAE 34 and EN 378, which means that the substance has low toxicity and will not spread flame at $18^{\circ} \mathrm{C}$ and $101300 \mathrm{~Pa}$. R449A contains no chlorine so its ODP (Ozone Depletion Potential) is zero.

Regarding its chemical stability, R449A is more sensitive to decomposition in the presence of air. During the breakdown of molecules, fluoride ions and organic acids occurs which are destructive to the POE oil and corrosive to the expansion valves and sliding components. Basic disadvantage of R449A application is its temperature glide from 1.5 to $5 \mathrm{~K}$ depending on operating conditions.

R744 refrigerant (carbon dioxide $\mathrm{CO}_{2}$ ) has a long tradition in refrigeration technology, dating back to the 19th century. It has ODP $=0$ and GWP $=1$. Besides it is chemically neutral, non-flammable, non-toxic directly, but the allowable carbon dioxide content in the air is lower than HFCs and special safety devices and $\mathrm{CO} 2$ detection systems may need to be installed in enclosed spaces. There is no need to recover and disposal. Its high specific volumetric cooling capacity, which, depending on the operating parameters, is from 5 to 8 times higher than HFCs. 
Other key features regarding the properties of CO2 compared to other HFCs are higher operating pressure at the same temperature, narrower operating temperature range and triple point at much higher pressure (-56.5oC; 5.18 bar $)$. The critical point at the low temperature $\left(31.0^{\circ} \mathrm{C} ; 73.75\right.$ bar $)$ is a problem but technically to overcome thanks to supercritical cycles.

R717 refrigerant (Ammonia) is old and still very good solution for refrigeration plants. Its molecular weight is 17 and boiling point is $-2.22^{\circ} \mathrm{C}$ ). Ammonia has highest refrigerating capacity per mass unit of any refrigerant and a number of other excellent thermal properties. However, it is toxic, explosive and flammable within certain conditions. Ammonia is used as refrigerant prominently in the refrigeration systems of food industry like dairies, ice creams plants, frozen food production plants, cold storage warehouses, processors of fish, poultry and meat and number of other applications [1].

\subsection{Assumptions for refrigeration system}

For further comparative analysis assumptions should be taken into consideration. Underneath, there are some of them for modelling of meat refrigeration plant.

- Freezing product: pork;

- Input temperature of product: $+15^{\circ} \mathrm{C}$;

- Mass of meat: 40 tonne per day;

- Doors opening time: 3 hours per day.

Information about dimensions of chambers and freezing channels with their demand of refrigeration capacity are shown in Table 1 [8].

Table 1. Dimensions and refrigeration capacity demand of refrigeration objects

\begin{tabular}{|c|c|c|c|c|c|c|}
\hline \multirow{2}{*}{ Chamber } & \multicolumn{3}{|c|}{ Dimensions $[\mathrm{m}]$} & \multirow{2}{*}{$\begin{array}{c}\text { Chamber } \\
\text { volume }\left[\mathrm{m}^{3}\right]\end{array}$} & \multirow{2}{*}{$\begin{array}{l}\text { Temperature inside } \\
\text { the chamber }\left[{ }^{\circ} \mathrm{C}\right]\end{array}$} & \multirow{2}{*}{$\begin{array}{l}\text { Refrigeration } \\
\text { capacity }[\mathrm{kW}]\end{array}$} \\
\hline & Length & Width & Height & & & \\
\hline $\begin{array}{c}\text { Freezing } \\
\text { chamber I }\end{array}$ & 45 & 15 & 9 & 6075 & $-22 \div-25$ & 90 \\
\hline $\begin{array}{c}\text { Freezing } \\
\text { chamber II }\end{array}$ & 30 & 15 & 9 & 4050 & $-22 \div-25$ & 60 \\
\hline $\begin{array}{l}\text { Tunnel } \\
\text { freezer }\end{array}$ & 15 & 11 & 5 & 825 & $-33 \div-35$ & 220 \\
\hline
\end{tabular}

In the following chapters of this article, detailed operating parameters of the three analyzed refrigeration systems were defined.

\subsubsection{One-stage refrigeration systems based on R449A}

Freezing chamber I is equiped with 4 air coolers using 4 compressors in one system. Freezing chamber II is equiped with 2 air coolers using 3 compressors in one system. Tunnel freezing is equipped with 4 air coolers using 2 independent systems with 3 units ( 2 air coolers per 3 compressors). This solution protects against a complete loss of refrigeration capacity during a failure, because while one chiller is down, the others one can work [21].

Table 2. Temperatures in freezing chambers I and II for R449A refrigerant

\begin{tabular}{|c|c|c|}
\hline Condensation temperature & $\mathrm{t}_{c, 449 A}$ & $42.00^{\circ} \mathrm{C}$ \\
\hline Condensation pressure & $\mathrm{p}_{c, 449 A}$ & $17.46 \mathrm{bar}$ \\
\hline Evaporation temperature & $\mathrm{t}_{o, 449 A}$ & $-32.00^{\circ} \mathrm{C}$ \\
\hline Evaporation pressure & $\mathrm{p}_{o, 449 A}$ & $1.47 \mathrm{bar}$ \\
\hline
\end{tabular}


Table 3. Temperature in tunnel freezer (refrigerant R449A)

\begin{tabular}{|c|c|c|}
\hline Condensation temperature & $\mathrm{t}_{c 449 A}$ & $42.00^{\circ} \mathrm{C}$ \\
\hline Condensation pressure & $\mathrm{p}_{c 449 A}$ & $17.46 \mathrm{bar}$ \\
\hline Evaporation temperature & $\mathrm{t}_{o 449 A}$ & $-41.00^{\circ} \mathrm{C}$ \\
\hline Evaporation pressure & $\mathrm{p}_{o 449 A}$ & $0.91 \mathrm{bar}$ \\
\hline
\end{tabular}

Table 4. Electric power demand of refrigeration systems (refrigerant R449A)

\begin{tabular}{|c|c|c|c|}
\hline Chamber & Equipment & Number & $\begin{array}{c}\text { Electric } \\
\text { power demand }[\mathrm{kW}]\end{array}$ \\
\hline \multirow{4}{*}{ Freezing chamber I } & Compressor unit & 1 & 68.40 \\
\hline & Refrigerant tank 150L & 1 & - \\
\hline & Condenser & 1 & 9.84 \\
\hline & Air cooler & 4 & 7.20 \\
\hline \multirow{4}{*}{ Freezing chamber II } & Compressor unit & 1 & 40.70 \\
\hline & Refrigerant tank 80L & 1 & - \\
\hline & Condenser & 1 & 7.20 \\
\hline & Air cooler & 2 & 4.20 \\
\hline \multirow{5}{*}{ Tunnel freezer } & Compressor unit & 2 & 261.60 \\
\hline & Refrigerant tank 150L & 2 & - \\
\hline & Oil cooler & 2 & 5.80 \\
\hline & Condenser & 2 & 19.68 \\
\hline & Air cooler & 4 & 38.40 \\
\hline
\end{tabular}

\subsubsection{Cascade refrigeration system with $\mathrm{R} 134 \mathrm{a} / \mathrm{R} 744$ refrigerants}

Freezing chamber I is equipped with 4 air coolers with 2 compressors working in low temperature cycle with R744 refrigerant. High temperature cycle is working with 3 compressors charged with R134a refrigerant. One of the R744 compressors and one of the R134a compressors will be equipped with a frequency converter to provide smooth refrigeration capacity control.

Freezing chamber II is equipped with 2 air coolers with 2 compressors working in low temperature cycle with R744 refrigerant. High temperature cycle is working with 3 compressors charged by R134a refrigerant. One of the R744 compressors and one of the R134a compressors are equipped with a frequency converter to provide smooth refrigeration capacity control.

Tunnel freezing is equipped with 4 air coolers using 2 independent systems (2 air coolers for each system). This solution provides greater reliability and safety. Then it is ability to operate at half capacity during a failure and maintenance to be performed by shutting down one of the system while the other is still running.

Low temperature cycle charged by R744 refrigerant is working with 2 compressors. High temperature cycle is working with 3 compressors charged by R134a refrigerant. One of the R744 compressors and one of the R134a compressors are equipped with a frequency converter to provide smooth refrigeration capacity control as needed.

The condensation temperature of the carbon dioxide and the temperature difference in the cascade heat exchanger (the boiling temperature of the R134a refrigerant) are influencing on working load of low and high temperature cycle's compressors respectively $[2,9,16]$. As the condensation temperature of carbon dioxide decreases both the power of low temperature cycle's compressors and the final temperature of compression are reducing. However, this has a negative impact on the high temperature cycle because it must take more heat from the condensing R744. For 
Table 5. Temperature in freezing chambers I and II for R134a/R744 cascade system

\begin{tabular}{|c|c|c|}
\hline \multicolumn{3}{|c|}{ R134a (high-temperature cycle) } \\
\hline Condensation temperature & $\mathrm{t}_{c, 134 a}$ & $42.00^{\circ} \mathrm{C}$ \\
\hline Condensation pressure & $\mathrm{p}_{c, 134 a}$ & $10.72 \mathrm{bar}$ \\
\hline Evaporation temperature & $\mathrm{t}_{o, 134 a}$ & $-12.00^{\circ} \mathrm{C}$ \\
\hline Evaporation pressure & $\mathrm{p}_{o, 134 a}$ & $1.85 \mathrm{bar}$ \\
\hline \multicolumn{3}{|c|}{ R744 (low-temperature cycle) } \\
\hline Condensation temperature & $\mathrm{t}_{c, 744}$ & $-8.00^{\circ} \mathrm{C}$ \\
\hline Condensation pressure & $\mathrm{p}_{c, 744}$ & $28.03 \mathrm{bar}$ \\
\hline Evaporation temperature & $\mathrm{t}_{o, 744}$ & $-32.00^{\circ} \mathrm{C}$ \\
\hline Evaporation pressure & $\mathrm{p}_{o, 744}$ & $13.34 \mathrm{bar}$ \\
\hline
\end{tabular}

Table 6. Temperature in tunnel freezer for R134a/R744 cascade system

\begin{tabular}{|c|c|c|}
\hline \multicolumn{3}{|c|}{ R134a (high-temperature cycle) } \\
\hline Condensation temperature & $\mathrm{t}_{c, 134 a}$ & $42.00^{\circ} \mathrm{C}$ \\
\hline Condensation pressure & $\mathrm{p}_{c, 134 a}$ & $10.72 \mathrm{bar}$ \\
\hline Evaporation temperature & $\mathrm{t}_{o, 134 a}$ & $-12.00^{\circ} \mathrm{C}$ \\
\hline Evaporation pressure & $\mathrm{p}_{o, 134 a}$ & $1.85 \mathrm{bar}$ \\
\hline \multicolumn{3}{|c|}{ R744 (low-temperature cycle) } \\
\hline Condensation temperature & $\mathrm{t}_{c, 744}$ & $-8.00^{\circ} \mathrm{C}$ \\
\hline Condensation pressure & $\mathrm{p}_{c, 744}$ & $28.03 \mathrm{bar}$ \\
\hline Evaporation temperature & $\mathrm{t}_{o, 744}$ & $-41.00^{\circ} \mathrm{C}$ \\
\hline Evaporation pressure & $\mathrm{p}_{o, 744}$ & $9.33 \mathrm{bar}$ \\
\hline
\end{tabular}

a carbon dioxide condensation temperature of $-4^{\circ} \mathrm{C}$ the enthalpy difference between saturated vapour and saturated liquid is $242.55 \mathrm{~kJ} / \mathrm{kg}$. However, for a temperature of $-10^{\circ} \mathrm{C}$ this value is $258.62 \mathrm{~kJ} / \mathrm{kg}$. Lowering the condensation temperature of R744 one should also lower the evaporation temperature of R134a. Then the situation is reversed. As the evaporation temperature decreases, the enthalpy difference of the refrigerant decreases too [4, 11, 17].

The analysis of different configurations of $\mathrm{CO}_{2}$ condensing temperature and temperature difference in the cascade exchanger is shown in the graph below. It shows that the optimum carbon dioxide condensing temperature is $-8^{\circ} \mathrm{C}$ and the temperature difference in the cascade exchanger is $4^{\circ} \mathrm{C}$, resulting in an $\mathrm{R} 134 \mathrm{a}$ evaporation temperature of $-12^{\circ} \mathrm{C}$.

It is observed that decreasing the temperature difference in a cascade heat exchanger results in a continuous increase of EER. This is undoubtedly true, however heat exchange with infinitely small temperature difference is an ideal to which all heat exchanger manufacturers strive. Therefore, in this paper it is assumed that the achievable temperature difference between the fluids is $4^{\circ} \mathrm{C}$. 


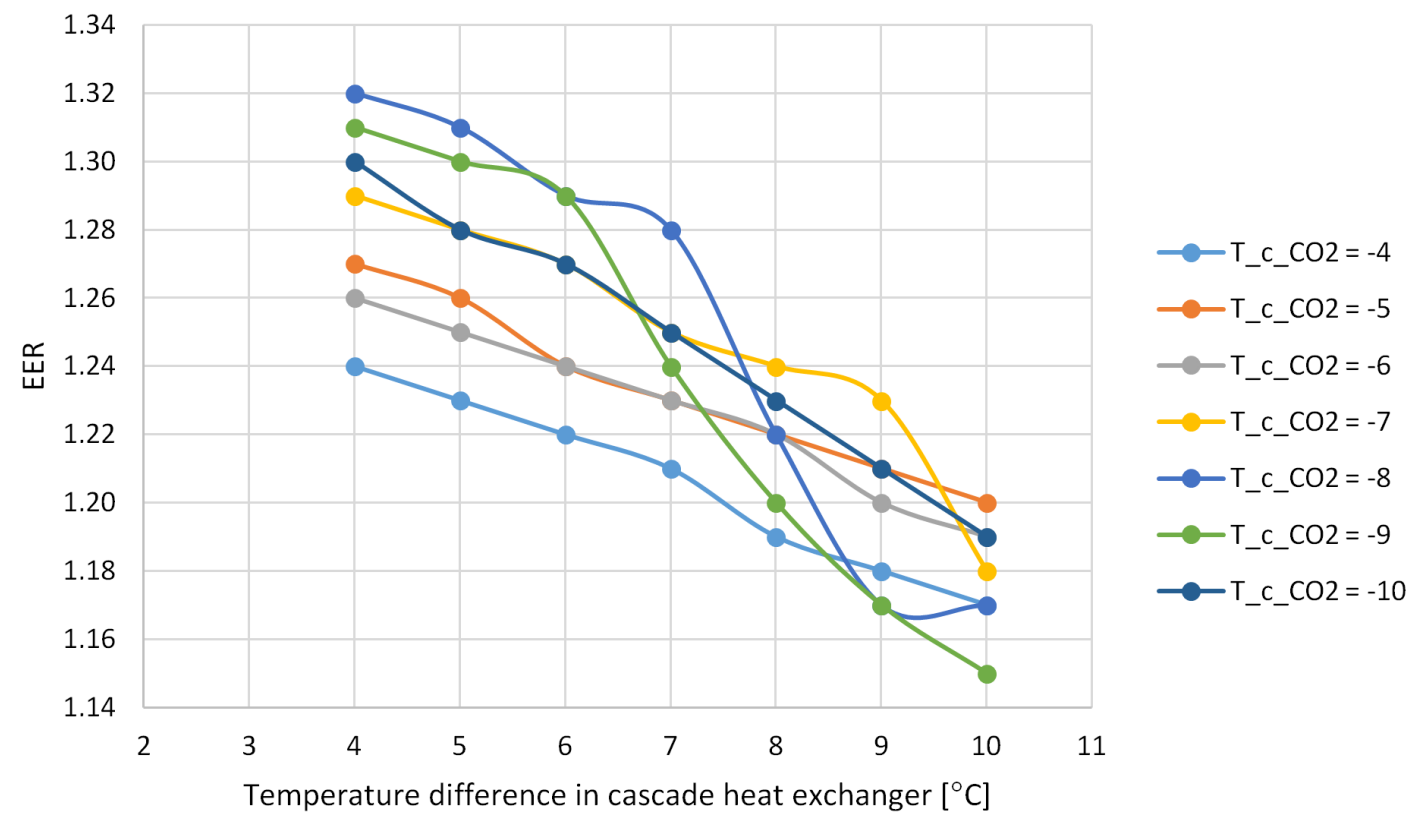

Figure 2. EER coefficient depending on both R744 condensation temperature and temperature difference in cascade heat exchanger

Table 7. Electric power demand of three refrigeration systems with R134a/R744 cascade system

\begin{tabular}{|c|c|c|c|}
\hline \multirow{5}{*}{ Chamber } & Equipment & Number & $\begin{array}{c}\text { Electric } \\
\text { power demand [kW] }\end{array}$ \\
\hline \multirow{5}{*}{ Freezing chamber I } & Compressor unit with R134a & 1 & 45.70 \\
\cline { 2 - 4 } & Refrigerant tank 150L & 1 & - \\
\cline { 2 - 4 } & Compressor unit with R744 & 1 & 20.80 \\
\cline { 2 - 4 } & Condenser & 1 & 8.20 \\
\cline { 2 - 4 } Freezing chamber II & Air cooler & 4 & 8.40 \\
\cline { 2 - 5 } & Compressor unit with R744 & 1 & 30.40 \\
\cline { 2 - 5 } & Refrigerant tank 100L & 1 & - \\
\cline { 2 - 5 } & Condenser & 1 & 8.80 \\
\cline { 2 - 5 } & Air cooler & 2 & 4.20 \\
\hline \multirow{5}{*}{ Tunnel freezer } & Compressor unit with R134a & 2 & 110.60 \\
\cline { 2 - 5 } & Refrigerant tank 150L & 2 & - \\
\cline { 2 - 5 } & Compressor unit with R744 & 2 & 73.60 \\
\cline { 2 - 5 } & Condenser & 2 & 19.68 \\
\cline { 2 - 5 } & Air cooler & 4 & 38.40 \\
\hline
\end{tabular}

\subsubsection{Refrigeration system with $\mathrm{R} 717$ (ammonia) refrigerant}

The ammonia plant was designed as a central plant with a cooling capacity to serve the whole facility. The coolers in the Freezing chambers I and II and Freezing tunnel will be powered by liquid ammonia pumps. Defrosting will be done with hot gas. The centralized installation allow to equip the facility with an additional cooler in the shipping 
room. It will be an under-ceiling cooler, operating in direct ammonia evaporation, equipped with electric heaters for defrosting.

Freezing chamber I is equipped with 4 air coolers and Freezing chamber II is equipped with 2 air coolers. Tunnel freezing is equipped with 4 air coolers. All air coolers are charged with 2 screw compressors.

Table 8. Parameters of ammonia refrigeration system

\begin{tabular}{|c|c|c|}
\hline Condensation temperature & $\mathrm{t}_{c, R 717}$ & $35.00^{\circ} \mathrm{C}$ \\
\hline Condensation pressure & $\mathrm{p}_{c, R 717}$ & $13.12 \mathrm{bar}$ \\
\hline Evaporation temperature & $\mathrm{t}_{o, R 717}$ & $-40.00^{\circ} \mathrm{C}$ \\
\hline Evaporation pressure & $\mathrm{p}_{o, R 717}$ & $0.72 \mathrm{bar}$ \\
\hline
\end{tabular}

Table 9. Electric power demand of three refrigeration systems with R744 (ammonia) refrigerant

\begin{tabular}{|c|c|c|c|}
\hline Overall cooling capacity & Equipment & Amount & $\begin{array}{c}\text { Electric } \\
\text { power demand }[\mathrm{kW}]\end{array}$ \\
\hline \multirow{11}{*}{$\mathrm{Q}_{o}=385 \mathrm{~kW}$} & Compressor unit & 1 & 323.80 \\
\hline & Condenser & 1 & 44.00 \\
\hline & Ammonia separator tank & 1 & - \\
\hline & Ammonia liquid pumps & 3 & 8.60 \\
\hline & Economizer & 1 & - \\
\hline & Liquid level regulating valve & 1 & - \\
\hline & Automatic oil system & 1 & - \\
\hline & Air cooler & 2 & \multirow{4}{*}{47.90} \\
\hline & Air cooler & 4 & \\
\hline & Air cooler & 4 & \\
\hline & Air cooler & 1 & \\
\hline
\end{tabular}

Table 10. Calculated overall energy efficiency of refrigeration EER based on equipment's data

\begin{tabular}{|c|c|c|c|}
\hline & $\begin{array}{c}\text { R449A refrigeration } \\
\text { system }\end{array}$ & $\begin{array}{c}\mathrm{CO}_{2} / \mathrm{R} 134 \mathrm{a} \\
\text { cascade refrigeration } \\
\text { system }\end{array}$ & $\begin{array}{c}\text { R717 refrigeration } \\
\text { system }\end{array}$ \\
\hline Refrigeration capacity $[\mathrm{kW}]$ & 372.40 & 390.40 & 464.00 \\
\hline Electric power $[\mathrm{kW}]$ & 463.02 & 383.18 & 424.30 \\
\hline EER & 0.80 & 1.02 & 1.09 \\
\hline
\end{tabular}

\section{Disscusion}

A single-stage refrigeration circuit operating with direct evaporation of refrigerant in evaporators is considered. The low evaporating temperature results in low efficiency of the system. The high evaporating and condensing pressure difference results in high energy consumption and low cooling capacity. Another disadvantage is the high service cost in case of loss of the refrigerant R449A, which is a multi-component mixture. In addition, with large quantities of refrigerant, European Union law requires the use of rather expensive stationary refrigerant detection system.

A cascade installation with R134a/R744 is characterized by low energy consumption in comparison with the cooling capacity. Cascade systems are considered to be the most modern and environmentally friendly solutions. Due to the 
use of synthetic refrigerant only in the second stage, carbon dioxide cooling circuit, the amount of working refrigerant in the installation can be significantly reduced. In case of leakage of carbon dioxide, the operator does not have to pay environmental charges and the price of gas is lower than for synthetic refrigerants. However, the capital cost of such installations is high. Since carbon dioxide has a high working pressure, pipelines have to be be made of materials with high mechanical strength. Because of the connection of two independent circuits to each other, it is necessary to ensure appropriate efficiency regulation by driving compressor engines with frequency converters and using an electronic expansion valve in the second stage circuit.

The last solution is the plant based on ammonia. Ammonia is a natural refrigerant with zero ODP and zero GWP. Ammonia plants are characterized by high EER. The pumped evaporator feed characteristic of ammonia plants provides very good heat transfer conditions in the refrigerated rooms $[12,13,19]$. The installation is the most durable among the presented ones, which is confirmed by ammonia installations operating for several dozen years. Ammonia is cheap, easily detectable due to its strong and characteristic smell detectable at health safe concentrations [10, 18]. Unlike synthetic refrigerants, ammonia detectors work very efficiently and are connected to the automatic emergency ventilation in the engine room. The disadvantages of this type of installation are the highest investment costs and the high factor filling due to the pump system. In addition, it is necessary to remember about the water treatment system necessary for the proper and long-term operation of evaporative condensers, as well as about daily professional service $[20]$.

\section{Conclusions}

In summary, producers of synthetic refrigerants show that they are able to meet the requirements of European Union legislation and produce new refrigerants that are less and less harmful to the environment. Unfortunately, these factors do not show the energy efficiency that is satisfactory for the users of the installation, which exposes the recipients to high operating costs. An increasingly popular alternative is the natural refrigerants that gave rise to refrigeration. And what should be emphasized, refrigeration is so needed today in many industries. By opting for slightly higher investment costs, you can use modern and more energy-efficient devices, and most importantly, without any legal restrictions. In the case of natural refrigerants, you can not worry about environmental fees or keeping device cards in the Central Register of Operators, which requires recording each service operation and carrying out periodic leakage checks. With current laws and regulations, it can be concluded that natural refrigerants will soon be replacing synthetic ones, and history will come full circle. Refrigeration will return to substances that were used at the dawn of time.

\section{References}

1. Ammonia Gas used as a Refrigerant in Refrigeration System https://www.brighthubengineering.com/hvac/ 64242-properties-of-ammonia-gas-or-r717-used-as-refrigerant/.

2. Bagiński, D. \& Bonca, Z. Ocena techniczno-ekonomiczna kaskadowego systemu chłodzenia opartego na układzie amoniak - dwutlenek węgla. Technika Chłodnicza i Klimatyzacyjna 2-4, 48-52 (2008).

3. Banaszek, J., Bzowski, J. \& Domański, R. Termodynamika. Przykłady i zadania (Oficyna Wydawnicza Politechniki Warszawskiej, Warszawa, 1998).

4. Bansal, P. A review - Status of CO2 as a low temperature refrigerant: Fundamentals and R and D opportunities. Applied Thermal Engineering 41, 18-29 (2012).

5. Baryłka, A. Effort of the protective structure of the shelter under the influence of an external fire. Archive of Mechanical Engineering 68, 183-193 (2021).

6. Bolaji, B. \& Huan, Z. Ozone depletion and global Warming: Case for the use of natural refrigerant - a review. Renewable and Sustainable Energy Reviews 18, 49-54. ISSN: 1364-0321 (2013).

7. Butrymowicz, D., Baj, P. \& Śmierciew, K. Technika Chłodnicza (Wydawnictwo Naukowe PWN SA, Warszawa, 2014).

8. Czapp, M. \& Charun, H. Bilans cieplny pomieszczeń chłodni. Zasady opracowania (Wydawnictwo Uczelniane Politechniki Koszalińskiej, Koszalin, 1997).

9. Dopazo, J., Fernandez-Seara, J. \& Sieres, J. Theoretical analysis of a CO2-NH3 cascade refrigeration system for cooling applications at low temperatures. Applied Thermal Engineering 29, 1577-1583 (2009).

10. Gruda, Z. \& Postolski, J. Zamrażanie Żywności (Wydawnictwo Naukowo-Techniczne, Warszawa, 1999).

11. Grzebielec, A. New refrigerants used by heat pumps. Modern Engineering 3, 100-106. ISSN: 2450-5501 (2020).

12. Kalinowski, K. Amoniakalne Urzadzenia Chłodnicze tom 2 (IPPU MASTA, Gdańsk, 2005). 
13. Kalinowski, K., Paliwoda, A. \& Bonca, Z. Amoniakalne Urządzenia Chłodnicze tom 1 (IPPU MASTA, Gdańsk, 2000).

14. Materiały szkoleniowe - Sympozjum Guentner 2015.

15. Rozporzadzenie Parlamentu Europejskiego $i$ Radu (UE) NR 517/2014 z dnia 16 kwietnia 2014 r. w sprawie fluorowanych gazów cieplarnianych i uchylenia rozporzadzenia (WE) nr 842/2006 (Tekst majacy znaczenie dla EOG) 2014.

16. Sanchez, D., Llopis, R. \& Cabello, R. Conversion of a direct to an indirect commercial (HFC134a/CO2) cascade refrigeration system: Energy impact analysis. International Journal of Refrigeration 73, 183-199 (2017).

17. Shariatzadeh, O., Abolhassani, S. \& Rahmani, M. Comparison of transcritical CO2 refrigeration cycle with expander and throttling valve including/excluding internal heat exchanger: Exergy and energy points of view. Applied Thermal Engineering 93, 779-787 (2016).

18. Szolc, T. Chłodnictwo. Podręcznik dla technikum. Wydanie szóste poprawione (Wydawnictwa Szkolne i Pedagogiczne, Warszawa, 1986).

19. Thermophysical Properties of Refrigerants chap. 30 (ASHRAE, 2009).

20. Urlich, H. Technika Chłodnicza tom 1 (IPPU MASTA, Gdańsk, 1998).

21. Wytyczne Tecumseh dla zastosowania R449A I R452A w nowych oraz istniejacych systemach chłodnictwa komercyjnego. Chłodnictwo i Klimatyzacja 02, 63-68 (2017). 